Mr. James Vernon to Walter Whitman. Drt. To one Hundred \& 1/4 Day.

Carpenter Work on the Meeting House at 8/. Per Day. $\$ 100.25$

To one Hundred Five and $1 / 2$ Days at $4 /$.

$\underline{52.75}$

$\$ 153.00$

Crt to Cash at Sundry times

$-\underline{73.00}$

Balance Due $\$ 80.00$

Crt to Cash

$\underline{10.00}$

$\$ 70.00$

Though it has long been known that the Whitman family was living in the East Norwich area in 1834 (with Thomas Jefferson Whitman born in July of that year), it was not certain what occupation Walter Sr. had turned to on bringing the family there from Brooklyn. The draft confirms that in this instance, at least, he turned from house building to the construction of a public building, however small. Walter Jr. was living independently in Brooklyn at the time where he worked as a school teacher; his first post was at the East Norwich school. A year later, when he taught a five-month term in Smithtown he received (in addition to room and board) $\$ 72.20 .^{2}$ While the terms of payment are not entirely clear in the church draft, it would appear that both Whitmans earned about the same amounts for their respective labors.

Hofstra University

JOANN P KRIEG

\title{
NOTES
}

1 I am grateful to Ms. Eileen McFretridge of the Community United Methodist Church for the church history she has compiled.

2 Jerome Loving, Walt Whitman: The Song of Himself. (Berkeley: University of California Press, 1999), 37.

\section{A CURIOUS COINCIDENCE: WHITMAN AND ALPHONSE KARR}

In 1845 , ten years before the publication of the first edition of Leaves of Grass, French readers of a book entitled Voyage autour de mon fardin [Travels 
around my Garden] could read this unexpected sentence: "Est-il un brin d'herbe qui ne soit un miracle au-dessus de toute les mythologies de tous les temps et de toutes les nations?" ["Is there a blade of grass which is not greater than all the mythologies of all times and all nations?"] In other words, is not a blade of grass an incarnation of God? This would not have been a bad answer to Whitman's inquisitive child who asked in "Song of Myself," "What is the grass?"2 In fact, the sentence might serve as a succinct summary of Leaves of Grass.

The author of Voyage autour de mon fardin was Alphonse Karr (1808-1890), a well-known journalist in those days, the author of "Les Guêpes" ["The Wasps"], a series of satirical tracts which indeed stung as they fearlessly and wittily attacked the corrupt and dishonest politicians who, in the reigns of King Louis-Philippe and Emperor Napoleon III, thought of nothing but making money. Karr was an idealist and a fervent republican. He was also a novelist whose potboilers sold fairly well. As Anatole France pointed out, the only part of Karr's works which had a chance to survive him was Voyage autour de mon fardin, for he always was a passionate gardener wherever he lived, at Sainte-Adresse near Havre and in Nice where he retired and spent the last years of his life as a market-gardener specializing in the cultivation of violets for the local perfume industry. ${ }^{3}$

Voyage autour de mon fardin is a collection of letters which Karr addressed to a friend who was fond of travelling abroad. He poked mild fun at him, claiming that he found more wonderful things in his garden than his friend could find at great expense in foreign countries. He described in particular how, before his own eyes, his flowers made love with their stamens and pistils. $\mathrm{He}$ thanked the birds for so wonderfully singing their amours and their love of life, and he celebrated the beetles and butterflies he met for the extraordinary metamorphoses they underwent, nothing short of marvelous apotheoses. His garden was a world in miniature where God gave free vent to his creative imagination. For him, as for Whitman, the physical world was a constant miracle and a perpetual source of wonder. There was, however, never any communication between the two writers. Whitman did not read French, and Karr's Voyage was not translated into English. It thus remains only a curious coincidence that they shared the same mystical worship of the grass as the symbol of universal and immortal life.

Université de Paris-Sorbonne

Roger AsSELINEAu

\section{NOTES}

1 Alphonse Karr, Voyage autour de mon fardin (Paris: Nelson \& Calmann-Lévy, [1910?]), Lettre XIV, 152.

2 Leaves of Grass, Comprehensive Reader's Edition, ed. Harold W. Blodgett and Sculley Bradley (New York: New York University Press, 1965), 33.

3 See Derek P. Scales, Alphonse Karr, sa vie et son oeuvre (Paris: Droz \& Minard, 1959). 